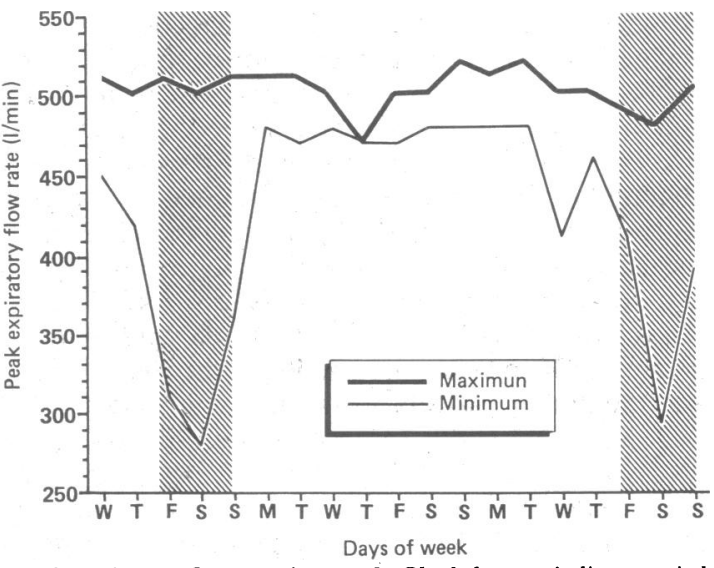

Peak expiratory flow rate in case 2. Shaded areas indicate periods when patient was at work

investigated, and thus the bronchoconstriction is unlikely to have been a non-specific irritant reaction. The absence of airway hyperresponsiveness may have been because the measurements were taken some weeks after the last exposure to the spray, but hyper- responsiveness is not invariably present in patients with occupational asthma. ${ }^{45}$ Challenge with the disinfectant spray produced an asthmatic response in both patients and supported the clinical diagnosis of occupational asthma due to this agent. The use of chlorhexidine-alcohol aerosols was stopped in the departments where these nurses worked, and they remained free of symptoms.

As this form of disinfection is widely used within the health service a large number of employees could be exposed to it. We have highlighted the risk within this health board and have notified both the manufacturers and the Committee on Safety of Medicines.

1 Ljunnggren B, Moller H. Eczematous contact allergy to chlorhexidine. Acta Derm Venereol (Stock) 1972;52:308-10.

2 Cheung J, O'Leary JJ. Allergic reaction to chlorhexidine in an anaesthetised patient. Anaesth Intensive Care 1985;13:429-30.

3 Hargreave FE, Ryan G, Thomson NC, et al. Bronchial responsiveness to histamine or methacholine in asthma: measurement and clinical significance. $\mathcal{F}$ Allergy Clin Immunol 1981;68:347-55.

4 Burge PS. Occupational asthma in electronics workers caused by colophony fumes: follow-up of affected workers. Thorax 1982;37:348-55.

5 Lozewicz S, Assoufi BK, Hawkins R, Newman-Taylor AJ. Outcome of asthma induced by isocyanates. Br f Dis Chest 1987;81:14-22.

(Accepted 19 January 1989)

\section{Impaired filterability of white cells in acute cerebral infarction}

\section{Giovanni Ciuffetti, Rani Balendra, Susan E Lennie, James Anderson, Gordon D O Lowe}

\section{Second Department of General Medicine and Medical Therapy, \\ Policlinico Monteluce, University of Perugia, 06100 Perugia, Italy \\ Giovanni Ciuffetti, MD, physician \\ University Department of Medicine, Royal Infirmary, Glasgow G31 2ER \\ Rani Balendra, $\mathrm{MB}$, research assistant \\ Susan E Lennie, HND, research assistant \\ James Anderson, MSC, research assistant Gordon D O Lowe, MD, senior lecturer}

Correspondence to: Dr Lowe.

BrMed f 1989;298:930-1 controls.

\section{Subjects, methods, and results}

The outcome of cerebral infarction after thromboembolism depends on the extent of residual microvascular perfusion. Whole blood filterability is reduced in acute stroke, ${ }^{1}$ but whether this reflects changes in plasma viscosity, fibrinogen concentration, packed cell volume, or the filterability of erythrocytes or leucocytes is not known. We therefore measured these variables in patients with acute stroke and in

We studied 39 patients with acute hemiparetic cerebral infarction, which had been confirmed by computed tomography in 24 and by the Guy's clinical score $^{2}$ in 15 , on the morning after admission. We also studied 11 patients of similar age with radiological evidence of acute chest infection (acute phase controls) and 61 asymptomatic controls, who were hospital staff or patients without vascular, infective, inflammatory, or malignant disease. Venous blood was anticoagulated with edetic acid $(1.5 \mathrm{~g} / \mathrm{l})$ for measurement of the packed cell volume, plasma viscosity (CoulterHarkness capillary viscometer; $37^{\circ} \mathrm{C}$ ), and fibrinogen

Results in four groups studied, expressed as means (SD)

\begin{tabular}{|c|c|c|c|c|}
\hline & \multicolumn{2}{|c|}{ Controls } & \multirow{2}{*}{$\begin{array}{l}\text { Patients with } \\
\text { cerebral } \\
\text { infarction }\end{array}$} & \multirow{2}{*}{$\begin{array}{l}\text { Patients with } \\
\text { chest infection }\end{array}$} \\
\hline & $<40$ Years & $\geqslant 40$ Years & & \\
\hline No in group & 30 & 31 & 39 & 11 \\
\hline No of men & 15 & 15 & 17 & 6 \\
\hline Age (years) & $28(4)$ & $68(11)$ & $71(11)$ & $73(11)$ \\
\hline Packed cell volume & $0.42(0.03)$ & $0.42(0.04)$ & $0.44(0.05)$ & $0.41(0.05)$ \\
\hline Viscosity (mPa.s) & $1.41(0 \cdot 10)^{\star \star \star}$ & $1 \cdot 46(0 \cdot 10)^{\star \star \star}$ & $1 \cdot 59(0 \cdot 12)$ & $1.54(0.20)$ \\
\hline Fibrinogen $(\mathrm{m} / \mathrm{l})$ & $26 \cdot 8(6 \cdot 9)^{\star \star \star}$ & $34 \cdot 2(7 \cdot 1)^{\star \star \star}$ & $49 \cdot 3(11 \cdot 6)$ & $47 \cdot 3(13 \cdot 6)$ \\
\hline \multicolumn{5}{|l|}{ Filtration variablest: } \\
\hline Erythrocytes & $0.496(0.036)$ & $0.498(0.041)$ & $0.497(0.053)$ & $0.486(0.041)$ \\
\hline Polymorphonuclear leucocytes & $3 \cdot 66(1 \cdot 10)^{\star \star \star}$ & $4 \cdot 20(0 \cdot 90)^{\star \star \star}$ & $5 \cdot 37(1 \cdot 23)$ & $4 \cdot 83(1 \cdot 95)$ \\
\hline Mononuclear leucocytes & $5.88(1.62)^{\star \star \star}$ & $7.57(1.84)^{\star \star \star}$ & $10 \cdot 32(2 \cdot 44)$ & $9 \cdot 58(2.38)$ \\
\hline
\end{tabular}

$\star \star \star \mathrm{p}<0 \cdot 001$. Compared with values obtained in patients with cerebral infarction (unpaired Wilcoxon test) †See text for definitions. concentration (by heat precipitation). Suspensions of blood cells in phosphate buffered saline $(\mathrm{pH} 7 \cdot 4$, $290 \mathrm{mmol} / \mathrm{kg}$ ) were filtered at $25( \pm 1)^{\circ} \mathrm{C}$ through filters with pores of diameter $5 \mu \mathrm{m}$ (Nuclepore, Pleasanton, California) after filtration of buffer. Flow variables were calculated relative to the values obtained with buffer. Erythrocytes were suspended at a packed cell volume of $0 \cdot 10$ and filtered (Carri-Med Filtrometer, Dorking) at constant pressure $(3 \mathrm{~cm}$ water), the relative initial flow rate being measured. ${ }^{3}$ Polymorphonuclear and mononuclear leucocytes were separated by Ficoll-Hypaque density gradient centrifugation, suspended at $10^{5} / \mathrm{ml}$, and filtered at constant flow $(1.5 \mathrm{ml} / \mathrm{min})$, the relative pressure at six minutes being measured. ${ }^{4}$

The table shows that there were no significant differences among the groups in the packed cell volume or filterability of erythrocytes. Plasma viscosity and fibrinogen concentration increased with age in the asymptomatic controls and were further increased in the patients with cerebral infarction. The most striking findings, however, were impaired filterability of leucocytes (increased relative pressure) in those controls aged 40 and over (mean difference from value in controls under $40=0.54$ (95\% confidence interval 0.02 to 1.06 ) for polymorphonuclear leucocytes and $1.69(0.80$ to 2.58$)$ for mononuclear leucocytes). Further impairment was seen in the patients with cerebral infarction compared with controls matched for age (mean difference $1.17(0.63$ to 1.71$)$ for polymorphonuclear leucocytes and 2.75 (1.69 to 3.81 ) for mononuclear leucocytes). Filterability of leucocytes was unrelated to sex, smoking habit, or death in hospital $(n=15)$, but in the patients with stroke fibrinogen concentration correlated with the filterability of polymorphonuclear leucocytes (Spearman's rank test, $r=0.43, p=0.01$ ) and of mononuclear leucocytes $(r=0.30, p=0 \cdot 08)$. Filterability of leucocytes in the patients with stroke was similar to that in the patients with chest infection, who also showed similar acute phase increases in fibrinogen concentration and viscosity.

\section{Comment}

We showed that reduced filterability of blood in patients with acute cerebral infarction ${ }^{1}$ is not due to changes in packed cell volume or the filterability of 
erythrocytes. It is partly explained by acute phase increases in plasma fibrinogen concentration and viscosity. In particular, however, we found that the filterability of both polymorphonuclear and mononuclear leucocytes is reduced in acute cerebral infarction. This may not only explain the reduced filterability of blood but also promote malperfusion of the microcirculation and infarction.

Reduced filterability of leucocytes may be part of the acute phase response to injury, as suggested by the correlation with fibrinogen concentration in the patients with stroke and by similar findings in the controls with chest infection. Preceding infection is an important risk factor for cerebral infarction. ${ }^{5}$ The risk of infarction also increases with age, and we observed decreased filterability of leucocytes in controls aged over 40 . We suggest that mechanisms by which increasing age and infections increase the risk of cerebral infarction include increased plasma fibrinogen concentration and viscosity and decreased filterability of leucocytes, each of which tends to reduce capillary flow.

This work was partly supported by grants from the Scottish Hospitals Endowment Research Trust and the Chest, Heart and Stroke Association.

1 Lorient-Roudaut MF, Manuau JP, Bricaud H, Boisseau MR. Filterability and cerebrovascular thrombosis. Scand f Clin Lab Invest 1981;41 (suppl 156):203-8

2 Sandercock PAG, Allen CMC, Corston RN, Harrison MJG, Warlow CP. Clinical diagnosis of intracranial haemorrhage using Guy's hospital score. Br Med F 1985;291:1675-7.

3 Dormandy JA, Flute PT, Matrai A, et al. The new St George's blood filtrometer. Clinical Hemorheology 1985;5:975-83.

4 Lennie SE, Lowe GDO, Barbenel JC, Forbes CD, Foulds WS. Filterability of white blood cell subpopulations, separated by an improved method. Clinical Hemorheology 1987;7:811-6.

5 Syriänen J, Valtonen VV, Iivanainen $M$, Kaste M, Huttunen JK. Preceding infection as an important risk factor for ischaemic brain infarction in young and middle aged patients. $\mathrm{Br}$ Med $\mathcal{F}$ 1988;296:1156-60.

(Accepted 12 fanuary 1989)

\title{
Progesterone cream for cyclic breast pain
}

\author{
I J McFadyen, G M Raab, C C A Macintyre, \\ A P M Forrest
}

University Department of Surgery, Royal Infirmary, Edinburgh

I J McFadyen, physician

A P M Forrest, FRCS, professor

Medical Statistics Unit, Medical School, University of Edinburgh, Edinburgh EH8 9AG

G M Raab, MSc, lecturer

C C A Macintyre, MSC, research associate

Correspondence to: $\mathrm{Mrs}$ Raab.

Br Med f 1989;298:931
Breast pain and nodularity during the luteal phase of the menstrual cycle may be due to insufficiency of progesterone. Local application of progesterone cream has been claimed to relieve these symptoms without affecting uterine function, but evidence that oral progesterone is effective is disputed. The use of progesterone cream for treating cyclic mastalgia has become popular in France after uncontrolled trials. ${ }^{1} \mathrm{~A}$ randomised trial of cream (C Conti, unpublished data) gave sufficiently favourable results to justify further studies.

\section{Patients, methods, and results}

Women attending our breast clinic with cyclic breast pain of at least two months' duration were included in the study. Women not menstruating regularly, taking the contraceptive pill, or with breast abnormalities were excluded. The women were asked to record their pain on a linear analogue scale from one to 100 daily from the first day of menstruation. ${ }^{2}$ The nodularity of the breasts was assessed by palpation on one day of the luteal phase of the cycle each month.

Patients who kept full records during a control month were randomised into the six month trial. They were asked to apply $5 \mathrm{~g}$ of cream each evening from the tenth day of one menstrual cycle to the first day of the next. Two different preparations in identical containers labelled first or second were used; one contained $1 \%$ natural progesterone and the other was without the active hormone. The active and placebo creams were applied for three months, each in random order, and only the statistician knew the order of the treatments. For each patient a mean pain score was calculated from the seven worst daily pain scores during the premenstrual phase each month. The seven worst days were usually consecutive and most often the days before the next period. The pain and nodularity scores for each patient were analysed by non-parametric tests, which compared differences within patients.

Thirty two women were entered into the study; 17 were randomised to use the active drug first and 15 the placebo. Seven did not return for their monthly appointments (usually after the first month). Thus complete data were available for 25 of the women, 14 of whom used the active treatment first and 11 the placebo.

The data were first analysed for trends in the pain and nodularity scores over time, but no evidence of any such trends was found. To compare the drugs a mean pain score and a total nodularity score were calculated for each patient's three month exposure to each drug.

Pain and nodularity scores in 25 patients with cyclic breast pain

\begin{tabular}{|c|c|c|}
\hline Outcome & Median score & $\begin{array}{c}\text { Median } \\
\text { (95\% confidence } \\
\text { interval) } \\
\text { difference } \\
\text { (active-placebo) }\end{array}$ \\
\hline $\begin{array}{l}\text { Mean pain score at } 3 \text { months } \\
\text { Total nodularity score over } 3 \text { monthst }\end{array}$ & $\begin{array}{r}44 \\
4\end{array}$ & $\begin{array}{l}3 \cdot 3^{\star}(-3 \text { to } 12) \\
1 \cdot 0^{\star}(0 \text { to } 1 \cdot 5)\end{array}$ \\
\hline
\end{tabular}

*Not significantly different from zero by Wilcoxon's signed rank test. † Sum of three monthly ratings, each of which was scored $0=$ none, $1=$ slight, $2=$ mild, $3=$ severe.

The results (table) showed a small but non-significant benefit from the placebo over the active drug. The confidence intervals indicated that any difference between the two preparations was small.

\section{Comment}

We have found that progesterone cream applied locally was no better than placebo cream in relieving breast discomfort. Attempts to determine whether the cream was absorbed into the circulation by daily measurement of salivary hormone concentrations was unsuccessful; this was because the samples contained high concentrations, which we found to be the result of contamination from cream on the patients' fingers.

Many of the oral treatments for mastalgia-for example, bromocriptine, danazol, and tamoxifen - can have troublesome side effects, ${ }^{34}$ and for a condition that can be self limiting their use is thus questionable. ${ }^{5}$ A topical treatment would be preferable, but unfortunately we showed that progesterone had no effect.

1 Mauvais-Jarvis P, Kuttenn NF, Ohlgiesser C. Resultats du traitement de mastodynies et de mastopathiel par la progesterone percutanée. Nouvelle Presse Medicale (Paris) 1974;3:1027-8.

2 Scott J, Huskisson EC. Graphic representation of pain. Pain 1976;2:175-84. 3 Pye JK, Mansel RE, Hughes LE. Clinical experience of drug treatments for mastalgia. Lancet 1985; ii:373-6.

4 Fentiman IS, Calefi M, Brame K, Chaudary MA. Double blind controlled trial of tamoxifen for mastalgia. Lancet 1986;i:287-8. 5 Preece PE. Mastalgia. Practitioner 1982;226:1373-81.

(Accepted 18 fanuary 1989) 